FEISCHMIDT MARGIT ${ }^{1}$

A KRITIKAI ÉS EMANCIPÁCIÓS DISKURZUSOK MEGÚJULÁSÁRÓL

Dol: $10.18030 /$ SOCIO.HU.2016.2.103

\title{
ABSZTRAKT
}

Írásomban két kritikai társadalomtudományi diskurzus, a multikulturalizmus és a feminizmus aktuális helyzetét elemzem. Vizsgálom a két társadalomkritikai perspektíva közös és eltérő társadalomfilozófiai alapelveit, valamint a képviselőik közötti vitákat is. Foglalkozom az emancipáció kelet-európai és magyarországi sajátosságaival, rámutatva az adaptáció hiányosságaira, továbbá az utóbbi időben terjedő ellenideológiák formáival és okaival.

Kulcsszavak: multikulturalizmus, társadalmi nemek, emancipáció, kisebbségek

\section{Multiculturalism AND FEMINISM REVISED}

\section{ABSTRACT}

The article examines the current state of two critical and emancipatory discourses in social sciences: multiculturalism and feminism. Similar and divergent elements of their theoretical position are investigated with a special emphasis on famous debates among their representatives. The limits of the East-European adaptation of multiculturalism and feminism alike are highlighted, whereas the social and political reasons of the current counter-ideologies (the "backlash multiculturalism" and the "anti-genderism") are also revealed in the paper.

Keywords: multiculturalism, gender, backlash discourses, emancipation, minorities

1 MTA Társadalomtudományi Kutatóközpont Kisebbségkutató Intézet 


\section{A KRITIKAI ÉS EMANCIPÁCIÓS DISKURZUSOK MEGÚJULÁSÁRÓL}

\section{BEVEZETÉS}

Írásomban két politikailag elkötelezett társadalmi és társadalomtudományi diskurzus, a feminizmus és a multikulturalizmus aktuális helyzetét elemzem. Úgy tekintek rájuk, mint a társadalmi különbségtételt értelmező paradigmákra, amelyek ugyanakkor elkötelezettek az egyenlőség, az igazságosság és szolidaritás mellett. Munkámnak van egy közéleti apropója: a férfiak és nők, szexuális és etnikai kisebbségek egyenlőségét megkérdőjelező politikai diskurzusok terjedése a közbeszédben. A tanulmány első és második fejezetében ezeknek a politikai diskurzusoknak az állításait és érveit vázolom fel, elsősorban Magyarország vonatkozásában, de kitekintéssel a hasonló szellemiségú nyugat-európai diskurzusokra is. A harmadik fejezetben bemutatom a két paradigma (a feminizmus és a multikulturalizmus) eredeti szándékait és szemléletét, amellett érvelve, hogy mindkettő az egyenlőség eszméjének kiterjesztéséből következik; az egyik a nők, a másik az etnikai- és kulturális kisebbségek irányába. A velük kapcsolatos kétségeket és kritikákat sem kerülöm el, azokat azonban nem a közéleti feminizmus- és multikulturalizmus-ellenességből vezetem le, hanem elsősorban azokból a vitákból, amelyek a két irányzat képviselői között az utóbbi két évtizedben felmerültek. Meggyőződésem, hogy a közösségi és egyéni, az univerzális és partikuláris értékek küzdelme elkerülhetetlen velejárója egy folyamatos változásban és mozgásban levő globális társadalomnak. Ezeknek a vitáknak néhány fontos szempontját az írás negyedik részében mutatom be. Végül az utolsó fejezetben elsősorban elméleti megfontolásból amellett érvelek, hogy a nemi emancipációt tagadó kultúrák elismerési törekvéseit és az egyenlőség univerzális elvének ellentmondásait a feminizmus és multikulturalizmus szempontjainak összebékítésével és a valósághoz való igazításával fel lehet és fel kell oldani.

\section{AZ ÚN. GENDER-PROBLÉMA}

Neményi Mária 1994-es, Miért nincsen Magyarországon nömozgalom? címú cikkében arra a kérdésre kereste a választ, hogy összefüggésbe hozható-e a nőmozgalom és a női perspektíva hiánya a magyar társadalom sajátos fejlődésével, a magyar nők társadalmi szerepének jellegzetességeivel. Válaszában, amelyben a szocialista típusú modernizáció, a paternalista állam által infantilizált társadalom és a második gazdaság által helyreállított premodern családi munkamegosztás hatását hangsúlyozta, a következő, máig időtálló megállapítást tette: „A kikényszerített modernizáció a hagyományos családdal kapcsolatos nosztalgiákat folyamatosan ébren tartotta. Ezekre a nosztalgiákra és a rendszerváltással felerösödött értékválságra jó eséllyel alapozhat a kormányzati politika, mely a társadalom regenerálódását többek között a keresztény, a nemi szerepek hagyományos megkülönböztetését fenntartó család rehabilitálásában látja. Ehhez a munkanélküliség rohamosan terjedő mértéke és a családokat támogató gyermekintézmények anyagi és ideológiai érvekkel alátámasztott zsugorítása is nagymértékben hozzájárul." (Neményi 1994:243) 
Ma, bő húsz évvel a fenti diagnózis megfogalmazása után még inkább látjuk, hogy gazdasági és társadalmi válságok idején felértékelődnek azok a politikai beszédmódok, amelyek a tradicionális értékeket helyezik előtérbe, azok rehabilitálásán keresztül fogalmaznak meg ígéreteket, pozitív jövőképet a társadalom számára. Ilyen érték a nemzet, amelynek a múlthoz kötődő, mítoszokból táplálkozó képéről a legtöbb szó esik; de a család is, amelynek aktuális társadalmi adottságokhoz való igazítása helyett azoknak a múltba projektált vízióknak a feltámasztására törekednek, amelyek a férfiak alkotó és vezető szerepére és a nők otthonteremtő és reproduktív funkciójára épülnek.

Egy, a közelmúltban napvilágot látott elemzés és egy konferencia arra hívta fel a figyelmet, hogy a nők egyenlőségének és a szexuális kisebbségek emancipációjának eszméjét ikonikusan hordozó „gender” diskurzus bírálata és lejáratása a politikai közbeszéd központi ügyévé vált (Kováts-Poim 2015). Miként a kutatók megállapították, noha országonként eltérő kérdések indították be az ellendiskurzust, ám az rövidesen mindenhol néhány tágabb téma körül csoportosult, mint például a reprodukciós jogok, gender-érzékeny tananyag bevezetésére irányuló oktatási reformok, melegházasság vagy abortusz kérdése stb. (Kováts-Põim-Tánczos 2015: 4-5). Amiként a diskurzust megalkotó és a társadalmi mozgósításban kulcsszerepet játszó aktorok is jelentős hasonlóságokat mutatnak európai összehasonlításban. A politikai pártok szerepét elemző tanulmányok rámutatnak, hogy a gender-ellenes mozgósítás olyan pártokat is összeköt, amelyek korábban nem múködtek együtt, és amelyek más témákban nem feltétlenül értenek egyet: számos konzervativ és szélsőjobboldali párt sorakozott fel a „gender-ideológia” „fenyegetése” ellen. A „gender” címkéje alatt nemcsak a nemek közötti egyenlőséget, a nők közéleti szerepét, vagy a szexuális kisebbségek jogait támadják. Ahogyan az elemzés szerzői fogalmaznak: „(A) "gender szinonimája lesz a homoszexualitás úgynevezett propagálásának, a nem és a szexuális orientáció szabad megválasztásának, a nemek állitólagos felszámolásának, valamint a pedofiliának, a gyerekek szexualizálásának, a »halál kultúrájának«. »Családfóbia«, »heterofóbia«, »homoszexualizmus« - ilyen és ehhez hasonló fogalmakkal indult nyelvi és definíciós küzdelem széleskörü társadalmi mozgalmak keretében. »Gender-ideológia«, »a gender-elmélet«, »gender-totalitarizmus«, »genderizmus«-ilyen kifejezések kerültek be a köztudatba egyik hónapról a másikra olyan társadalmakban, ahol a gender fogalomról korábban csak egy kisebb szakmai közönség tudott. A »gender-ideológia« mindeközben mint egy világméretű összeesküvés kerül bemutatásra, az ENSZ, az EU és a különbözö nemzeti kormányok részvételével, amely ellen a demokrácia és az úgynevezett józan paraszti ész iránt elkötelezett tudatos állampolgárnak, illetve az aggódó és felelös szülőnek feltétlenül fel kell lépnie" (Kováts-Soós 2014: 108).

Az elemzés és annak politikai tanulságait (Kováts-Põim-Tánczos 2015) megfogalmazó szerzőkkel egybehangzóan úgy látom, hogy a gender ellenideológia nem önmagában értelmezendő, nem csak a nők és a férfiak társadalmi viszonyáról és az egyenlőség ideáljáról szól. A gender fogalom a konzervatív mozgósítás szimbolikus eszköze, amelynek jelentését különböző politikai, közéleti és egyházi szereplők együttesen építik fel. Alkalmas arra, hogy megkérdőjelezze a huszadik századi, egyenlőségre és szabadságra épülő progresszív politikai nyelvet, illetve annak a szakpolitikákba és a politikai főáramba való beemelését. Hasonlóképpen ahhoz, ahogyan a kulturális és etnikai kisebbségeket emancipáló multikulturalizmus ellendiskurzusa is múködik, aminek az elmúlt években ugyancsak tanúi lehettünk a legkülönbözőbb hazai és nemzetközi médiumokban. 


\section{AZ ÚN. MULTIKULTURALIZMUS-PROBLÉMA}

A multikulturalizmus bumerángja nagyjából 2006-ban repült vissza az európai közbeszédbe, amikor a londoni robbantás évfordulóján a brit sajtóban megjelent a „A multikulturalizmus halott” felkiáltás. Négy évvel később Angela Merkel keltette a német multikulturalizmus halálhírét. Magyarországon Orbán Viktor 2015. május 19-i, Európai Parlamentben tett kijelentése - „Magyarország sosem volt multikulturális társadalom” indította el a lavinát. A miniszterelnök két legtöbbet idézett mondata így hangzik: „Meg vagyok arról győződve, hogy mivel nekünk, magyaroknak az ilyen konfliktusok kezelésére való képességeink nem fejlődtek ki, mert mi sohasem voltunk multikulturális társadalom, mi sohasem fogadtunk be a gyarmatainkról érkezett bevándorlókat, ezért a közép-európai térségben a bajok még annál is nagyobbak lennének, mint amit most sok nyugat-európai országban látunk. (...) Mi értéknek tekintjük azt, hogy Magyarország egy homogén ország, kultúrájában, gondolkodásmódjában, civilizációs szokásaiban meglehetősen homogén képet mutat. Szerintünk ez egy érték, és nem is szeretnénk ezt föláldozni. De nem akarjuk elvitatni azoknak az országoknak a jogát sem a bevándorlók befogadásához, akik egyébként ehhez hozzászoktak, és igy akarják megoldani a problémáikat" - fejezte be. ${ }^{2}$

Beszédével Orbán beszállt abba vitába, amely immár tíz éve folyik Európában a multikulturalizmus körül, még pontosabban elfoglalta helyét azok között, akik tagadják a multikulturalizmus lehetőségét. Másrészt Magyarország helyét kívánta kijelölni egy, a multikulturalizmus körül felépített fogalmi mezőben, amely a gyarmatosításról, a migrációról, egy elképzelt Nyugat és egy elképzelt Kelet közötti viszonyról szól. Orbán Magyarországa zárt, kulturálisan homogén ország, amely mindig kívül állt az erőforrásokért folyó globális versenyen, a gyarmatosításon és a nemzetközi migráció rendszerén. A kijelentés körül kialakuló vitát vizsgáló dolgozatban Torbó Annamária (2015) rámutat, hogy diskurzus és az ellendiskurzus dinamikáját legfőképpen a Kelet-Nyugat dichotómia határozza meg. Míg az anti-multikulturalista diskurzus kívül helyezi Magyarországot a modern Nyugaton, aminek elsősorban a deficitjeit hangsúlyozza, és ezért kiemelten a kulturális keveredést marasztalja el, az ellendiskurzus Magyarországot a Nyugathoz sorolja, többnyire annak pozitív morális konzekvenciáival együtt.

Az ellendiskurzus fő állítása, amely leghatározottabb formában az MTA TK Kisebbségkutató Intézet közleményében fogalmazódott meg („Magyarországon a kulturális sokszínüség tény és érték”3) két érvrendszerre épít, az egyik történeti, a másik a mai valóságra, a létező és államilag is elismert kisebbségekre hivatkozik. A történeti érveket alkalmazó cikkek azt taglalják, hogy „»Magyarország egy homogén ország, kultúrájában, gondolkodásmódjában, civilizációs szokásaiban meglehetősen homogén képet mutat éppen a nemzetinek tartott kormánya egyik fő toposzát, a trianoni tragédiát, és annak máig tartó hatását kérdőjelezte meg. (...) Magyarország ugyanis csak Trianon árán vált multikulti országból többé-kevésbé homogén nemzetállammá. (...) Trianon után vált az etnikai egység, a »tiszta " magyarság hajszolása igazi nemzeti bolondériává", amelynek célpontjai lettek a zsidók, továbbá a legnagyobb hazai kisebbséggé váló németek"4. Miközben az ellenzéki médiumok

2 http://index.hu/kulfold/eurologus/2015/05/19/orban_sosem_voltunk_multikulturalis_tarsadalom/ utolsó megtekintés 2016. május 24.

3 Nyilatkozat Magyarország kulturális sokszínúségéről, lásd: http://kisebbsegkutato.tk.mta.hu/hirek/2015/05/nyilatkozatmagyarorszag-kulturalis-sokszinusegerol utolsó megtekintés 2016. május 24.

4 http://index.hu/belfold/2015/05/20/orban_viktor_multikulturalizmus_magyarorszag_tortenelem_strasbourg/ 
nagy része arra törekszik, hogy a hazai kisebbségeket és a menedékkérőket együtt, egymás mellett kezelje, a kormányzati diskurzus a két csoportot szembehelyezi egymással: „Új magasságokba jutott a bevándorlás-vita: Trócsányi szerint mi azért nem tudunk gazdasági menekülteket fogadni, mert 800 ezer cigányról kell gondoskodnunk." ${ }^{\prime \prime}$

Ha a magyarországi vitát a nemzetközi párhuzamokkal összehasonlítjuk, megállapítható, hogy míg a multikulturalizmus tagadása hasonló érveket használva beépül az új európai konzervatív kánonba, e politikai diskurzus kritikusai nem tájékozódnak a multikulturalizmussal kapcsolatos nyugat-európai és észak-amerikai gondolkodást illetően. A Heti Válasz cikkírója egy autochton és többnyire történeti félreértésekre épülő „valódi multikulturalizmus" mellett érvel, miközben a migránsokkal kapcsolatban a stigmatizációs beszédet folytatja „Szerintem nem az a valódi multikulturalizmus, hogy beözönlik egymillió bevándorló, hanem az, ami Erdélyben vagy a Vajdaságban van, ahol az ott élő népek az évszázadok alatt megtanulták többé-kevésbé elviselni egymást..” A Mandiner szerzője ugyancsak historizál, továbbá új fogalmat alkot („plurietnikus ország”), hogy a multikulturalizmust egy antiglobalista pozícióból továbbá szándékos vagy szándékolatlan csúsztatásokat alkalmazva bírálni tudja: „Közép-Európának e szegletére hagyományosan a plurietnikus társadalmi modell jellemző, aminek klasszikus példája a Monarchia volt, ahol valóban több etnikum élt sorsközösségben egy ténylegesen soknyelvü országban, amit nem kéne nagy hirtelen összekeverni a globális gyarmattartás ideológiájaként kéthárom évtizede propagált multikultival, mely a gyakorlatban - hogy, hogy nem - gazdaságilag, nyelvileg és kulturálisan egyaránt az anglo-amerikai modell uralmát jelenti." ${ }^{7}$

Összefoglalásképpen megállapítjuk, hogy azt a lehetőséget, hogy a multikulturalizmus tagadása megjelent a magyarországi közbeszédben, a kormányzati kommunikáció kritikusai kifejezetten a kormányfő kritikájára tudták hasznosítani, arra azonban nem, hogy a magyarországi multikulturalizmust időszerúvé tegyék, és nemzetközi kapcsolódásait megteremtsék. A magyarországi multikulturalizmus-tagadók diskurzusa viszont annál sikeresebben épült be a nemzetközi kontextusba. Hasonlóképpen ahhoz, ahogyan a gender-ellenideológia az emancipált nőket és a homoszexuális viszony elismerését teszi felelőssé az európai társadalmak alacsony termékenységért, az anti-multikulturalista diskurzus a multikulturális politikát hibáztatja a migráció célországaiban megjelent etnikai zárványokért, mi több, a vallási fundamentalizmusért és a terrorizmusért is. A multikulturalizmus az európai társadalmakra kényszerként nehezedik, állítják, amit egy "fehér liberálisokból” és „kisebbségi aktivistákból” álló politikai elit erőltet rá a többségre. A közbeszédben uralkodóvá vált politikai korrektség megakadályozza a kulturális és vallási sokféleségből származó problémákkal való szembenézést. A multikulturalizmus által támogatott közpolitika relativizálja, sőt, a kisebbségi vallási fundemantalizmusok, elsősorban az iszlám támogatásával aláássa a közös értékeket és a nemzetállami lojalitást.

\footnotetext{
utolsó megtekintés 2016. május 24.

5 http://444.hu/2015/05/22/uj-magassagokba-jutott-a-bevandorlas-vita-trocsanyi-szerint-mi-azert-nem-tudunk-gazdasagimenekulteket-fogadni-mert-800-ezer-ciganyrol-kell-gondoskodnunk/ utolsó megtekintés 2016. május 24.

6 „Félreértik a multikulturalizmust”. Heti Válasz, 2015.05.28 http://valasz.hu/itthon/az-nem-multikulturalizmus-hogy-beozonlikegymillio-bevandorlo-113077?honnan=Nemzeti_Hirhalo utolsó megtekintés 2016. május 24.

7 http://mandiner.hu/cikk/20150527_kardos_gabor_kie_magyarorszag utolsó megtekintés 2016. május 24.
} 
Amiként a Multiculturalism Backlash (Vertovec-Wessendorf 2010) címú kötet szerzői rámutattak, a multikulturalizmus tagadása Európában egy olyan diskurzus részévé vált, amit „alulról”, a „kisemberek” nevében megszólaló nyílt beszéddel, a politikai „új realizmussal” legitimálnak annak múvelői. Látnivalóan nagy sikerrel. A diverzitás helyett a nemzetek egységesnek vélt kultúráját, valamint a kultúrában gyökerező felsőbbség tudatát („Leitkultur”) törekszenek megvalósítani. A multikulturalizmus ellenideológiája az európai országok többségében erősödik az utóbbi években. Hollandiában az 'új realizmus' hatására a migrációról, bevándorlókról szóló közbeszéd jelentősen átalakult, a konkrét közpolitikák viszont kevésbé változtak. Dániában a bevándorlásra adott kulturalista és nacionalista válasz a dán társadalom önképét sem hagyta változatlanul. Németország és Svájc a szerzők szerint sohasem volt igazán reflexív a bevándorlókhoz kötődő kulturális diverzitással kapcsolatban, alacsonyabb szinteken (pl. bizonyos nagyvárosokban) azonban még mindig meghatározó a multikulturális vagy interkulturális politika. A multikulturalizmus-bumeráng mindenhol a médián keresztül hat elsősorban, sőt, amiként Peter Hervik a dán esettel kapcsolatban rámutatott, sok szempontból a média találja ki azt olyan eseményekhez kötve, amelyekkel félelmet vagy iszonyatot tud kelteni (Hervik 2015).

A fentiekben arra igyekeztem rámutatni, hogy a gender- és multikulturalizmus-ellenes közbeszédnek számos közös eleme van. Ennek legfőbb oka, hogy mindkettő egy átfogóbb diskurzus része, amely túlmutat a kulturális vagy etnikai kisebbségek, a férfiak és nők egyenlőségének kérdésein. Azt a normatív alapállást képviseli, hogy az emancipáció és a szabadság kiterjesztése veszteségekkel járt (a család tekintélyének lerombolása, reprodukció visszaesése, a kulturális tájékozódás biztonságának, a közösségek megtartó erejének szétesése). A korábbi status quo élhetőbb és biztonságosabb volt, ezért azt helyre kell állítani. A restaurációt pedig a legnagyobb veszteségnek tekintett „tradicionális” nemi és etnikai rend helyreállitásával kell elkezdeni. A teljes állítás igazságával nem fogok ebben az írásban foglalkozni, mert normatív szempontból nem értek vele egyet, szociológiai szempontból elemezni pedig - ugyan érdekes és fontos volna - nem tekintem itt és most feladatomnak. Azzal azonban foglalkozni kívánok, hogy a kétféle különbségtétel és egyenlőség (a nemi és a kulturális) milyen ellentmondásokat hordoz, és azokat a két emancipációs diskurzus miként kezelte. Mielőtt azonban rátérnék a feministák és a multikulturalisták vitájának bemutatására, előbb egyenként bemutatom a két szellemi irányzatot, hogy viszonyuk későbbi értelmezését megkönnyítsem.

\section{A FEMINIZMUS ÉS A MULTIKULTURALIZMUS}

A hatvanas években induló új társadalmi mozgalmak (közöttük a feminizmus és a multikulturalizmus) a társadalmi igazságosság és egyenlőség mellett szálltak síkra. A hatásukra a szociológiában és más társadalomtudományokban is erősödő társadalomkritikai beszédmód az egyenlőség hiányára irányítja a figyelmet, az egyenlőtlenség újratermelődését igyekszik feltárni. Iris Marion Young úttörő írásában az elnyomás múködését így azonosítja: „Ebben a kiterjesztett strukturális értelemben az elnyomás azon számtalan, mély igazságtalanság összessége, melyeket az egyes csoportoknak (és rajtuk keresztül az egyéneknek) el kell szenvedniük a jó szándékú emberek egyszerü interakcióinak, a média és a kulturális élet sztereotípiáinak, a bürokratikus hierarchia, illetve a piaci mechanizmusok strukturális sajátosságaiban megnyilvánuló gyakran tudattalan feltétezéseknek és reakcióknak - röviden a mindennapi élet normális folyamatainak következményeként. Nem tudjuk ezt a strukturális elnyomást az uralkodók eltávolításával, vagy néhány törvény meghozatalával megszüntetni, 
mivel az elnyomást módszeresen újratermelik a jelentős gazdasági, politikai és kulturális intézmények" (Young 2001:13).

Az elnyomást aszerint, hogy kikre irányul, lehet rasszizmusként, szexizmusként, homofóbiaként, ageizmusként, stb. értelmezni. Az elnyomás okaira vonatkozóan két elképzelés létezik: I. különböző formáinak önálló dinamikájuk van, és egymástól függetlenül múködnek; II. mindegyik az osztályuralom következménye. Young nem foglal állást az okokról szóló vitában, elsősorban a hatalom formáira és dinamikájára figyel, aminek alapján az elnyomás öt formájáról beszél: (1) a kizsákmányolásról, amin a különböző erőforrások csoport alapú és strukturálisan újratermelt egyenlőtlen elosztását érti; (2) a marginalizációról, ami a munkaerőpiac által érvényesülő anyagi megfosztottságot jelenti, számos azon túl mutató következménnyel; (3) a hatalomnélküliségről, ami a döntéshozatalban való egyenlőtlen részvételből fakad, és az egyéni képesség kibontakoztatásának akadályoztatása következik belőle; (4) a kulturális imperializmusról, ami egyenlőtlen hozzáférést jelent az értelmezés és a kommunikáció eszközeihez, ezzel a domináns csoport tapasztalatainak univerzalizásához, normaként való beállításához vezet, míg a dominált csoportok tagjait sztereotípiákkal jelölik vagy láthatatlanná teszik; (5) és az erőszakról, amelyeknek azért esnek áldozatul emberek, mert bizonyos csoportok tagjai; de ami az erőszakot az elnyomás egyik módjává teszi, azok nem is maguk a tettek, hanem az a társadalmi környezet, amely elfogadhatóvá teszi ezeket a tetteket.

A társadalmi mozgalmakhoz kapcsolódó diskurzusok azonban nemcsak az elnyomás strukturális okait elemzik, hanem az elnyomást interiorizáló identitásokat is. Továbbá olyan politikai víziókat fogalmaznak meg, amelyek az egyenlőség megvalósítását és a felszabadítás módját értelmezik. Ez a liberális jogállam keretei között kétféleképpen valósulhat meg: a tolerancia által, ami a különbözés jogát védi, de a magánszférára korlátozza, és az anti-diszkrimináció által, ami az egyéni jogokat védi univerzális keretben. A multikulturalizmus egy harmadik, sokak szerint a liberális demokráciák kereteit feszegető alternatíva, amely a közösségek kollektív jogait részesíti előnyben azt vallva, hogy az egyéni szabadság és boldogulás csak a kulturális csoporthoz való akadálytalan tartozás révén valósulhat meg. Marion Young megközelítése is az utóbbihoz áll közel, azt vallja ugyanis, hogy a társadalmi igazságosság nem a különbség felszámolását igényli, hanem olyan intézményeket, amelyek lehetővé teszik a csoportkülönbségek újratermelését és tiszteletét.

Charles Taylor, a multikulturalizmus politikai filozófiájának megalapozója azt állítja, hogy a 20. század második felében, elsősorban a polgárjogi és feminista mozgalmak hatására megváltozott a politika értelme, a politika kulcsfogalma az elismerés lett, aminek nyomatékot az identitás és az elismerés kapcsolata ad. A politikai küzdelmek tárgya az egyenlő elismerés, ami két módon valósulhat meg. Egyrészt az univerzalizmus politikája által, amelynek alapja minden polgár egyenlő méltósága, univerzális emberi képessége. Másrészt megvalósulhat a különbség politikája által, ahol az elismerés tárgya személyek vagy csoportok egyedi identitása, mindenki mástól való különbsége, sajátossága, „kultúrája” (Taylor 1995). Az utóbbi elképzelést valósítja meg a multikulturalizmus, nem függetlenül azonban attól az előzménytől, amit a feminizmus képviselt azáltal, hogy elsőként tette az identitást a politika tárgyává, és jelölte meg a politika célját a sajátosság (a nők és a nőiség) elismerésében. 
Az identitáspolitikák között úttörő szerepet játszó feminizmus képviselői között egyetértés van a nemi egyenlőtlenség felismerését és helytelenítését illetően, különbség van viszont az egyenlőtlenség felszámolásának módjára vonatkozóan. A liberális feminizmus szerint a törvény előtti egyenlőség (a szavazati jog, a tanuláshoz való jog, a munkához való jog egyenlősége) a társadalmi egyenlőtlenség megszüntetésének szükséges és elégséges feltétele. A liberális feministák szerint az egyenlőség az adott társadalmi viszonyok között, azok részleges reformjával is elérhető. Ezzel szemben a marxista feminizmus szerint a változtatás az egész kapitalista társadalmi rendre ki kell, hogy terjedjen, amely a fizetetlen munka és szexuális szolgáltatások révén a nemi elnyomást inkorporálja. Mivel az egyenlőtlenség oka nemcsak a férfiak által megvalósított elnyomás, hanem a nők természet általi meghatározottsága, „testbe zártsága”, az egyenlőség csak a nők biológiai determináltság alól való felszabadítása által valósulhat meg. A kibontakozó kisebbségi polgárjogi mozgalmakra leginkább a feminizmus harmadik hulláma volt hatással, amely a nőiességben rejlő sajátos értékekre helyezi a hangsúlyt. A mozgalom a női értékek tudatosítására épül, a férfiuralom alól felszabadult női hang megszólaltatására törekszik.

A multikulturalizmus a kisebbségi és többnyire hátrányos helyzetú nyelvi, vallási és etnikai közösségek helyzetét azonosító kritikai és normatív diskurzus. Kritikai azért, mert a többkultúrájúság tényének megállapításán túl bírálja a társadalmi kizsákmányolás, az etnikai diszkrimináció és a kulturális hegemónia folyamatait, amelyek szégyent, az alacsonyabbrendúség érzetét keltik az elnyomott közösségek tagjaiban. A multikulturalizmus ugyanakkor normatív diskurzus is: az egyenlőséget tekinti értéknek, amelyet pedig nem egyéni, hanem közösségi szinten, a közösségeket pedig kulturális terminusokban értelmezi. Hogy a kulturális sokféleség egy társadalomban érték, az azt jelenti, hogy a különböző származású és hagyományokat követő emberek egyenlő méltóságát tisztelik, mi több, kulturális szokásaik gyakorlását az állam (anyagi és szimbolikus eszközökkel) támogatja. Ha ez megtörténik, akkor a megsértett méltóság is helyreállítható, az elnyomott identitás felszabadítható.

Az identitáspolitika általában a kultúrát választja a felszabadítás eszközéül. A kultúrát tehát kollektív értékként tételezi, amit egy közösségnek meg kell védenie ahhoz, hogy elismerésre tegyen szert. Ez sokakat arra enged következtetni, hogy a kultúra állandó, homogén és objektív, ami tényszerűen nem igaz, és csak a politikai céljaik által elvakított multikulturalisták vallják. A társadalmi folyamatokkal és politikai küzdelmek mechanizmusaival tisztában levő kritikai multikulturalisták tudják, hogy a kultúra, bár annak látszik, nem objektív adottság, hanem a valóság darabjaiból (pl. közös nyelv, normák, rítusok, mindezekhez kötődő kollektív érzések) a politikai cselekvés számára konstruált szimbolikus eszköz. A különbség politikája egy másik ambivalenciát is hordoz: az egalitárius retorikát az autenticitás diskurzusával ötvözi. Ahogyan Christian Joppke (1998) ezt nagyon találóan megfogalmazta: a multikulturalizmus az egyenlőség és az emancipáció melletti elkötelezettsége okán kifejezetten baloldali mozgalomnak túnik; mégis, a partikularisztikus, askriptív csoport-identitásoknak való elkötelezettsége miatt eltér a baloldal univerzalista szemléletétől, és a hagyományosan a politikai jobboldalhoz tartozó területre lép. Vagyis egyszerre partikularisztikus és univerzalista, modern és antimodern, amiből számos értelmezési nehézség származik, ugyanakkor azt az esélyt is hordozza, hogy a politikai ideológiák dichotómiáit meghaladja. 
TÉNYLEGES PROBLÉMÁK. A NEMI EGYENLŐSÉG UNIVERZALIZMUSÁNAK ÉS AZ ANTIEGALITÁRIUS KULTÚRÁK ELISMERÉSÉNEK ELLENTMONDÁSAI

A multikulturalizmussal szembeni kritikák egyik legfőbb oka a liberálisok procedurális és egyéni jogfelfogása és a multikulturalisták kollektív jogfelfogása közötti különbség (Habermas 1995). A kultúrához is másként viszonyulnak: amit egyik oldalon kollektív jószágként, másik oldalon lehetőségként értelmeznek. A multikulturalizmussal szembeni érvek közül a legerősebb mégiscsak az, hogy az elnyomással szemben válogatás nélkül védett közösségeknek vannak tradíciói, szokásai, praxisai, amelyek ellentmondanak a polgári demokráciák alapvető értékeinek, a személyek szabadságának és egyenlőségének.

Az univerzalisták és partikularisták legfontosabb vitája a feministák és a multikulturalizmus hívei között bontakozott ki. A vita egyik karakteres álláspontját megfogalmazó nyugati multikulturalisták azt vallják, hogy a modern világban a nemi emancipációt befejezettnek lehet tekinteni, tehát nem kell aggódni amiatt, hogy a kisebbségi csoportok megerősítése akár a kisebbség, akár a többség korábban kivívott nemi egyenlőségét veszélyeztetné. Mi több, úgy hitték, hogy a női emancipáció több évtizedes tapasztalata tanulságokkal szolgálhat a kulturális és etnikai kisebbségek felszabadítása számára is. A multikulturalizmus kisebbségi vagy nem nyugati képviselói még inkább negligálták a nemi egyenlőtlenség kérdéseit, egyrészt mert sokkal fontosabb célnak gondolták a kisebbségi csoportok védelmét és közösségként való fenntartását, másrészt, mert a közösségeken belüli domináns férfihang hegemóniáját védték. A multikulturalizmus jeles képviselői közül senki sem gondolta komolyan végig a nemi és kulturális meghatározottság viszonyát és az ebből adódó konfliktusokat. Kymlicka érvelésében a kisebbségi származású és kötődésű egyén, akinek a szocializációja és méltósága csak úgy teljesedhet ki, ha a kulturális közösség fennmaradása garantált, nem rendelkezik nemmel, vagyis nemtelen (Kymlicka 1998).

Ennél megrázóbbak azonban azok a női hangok, amelyek kisebbségi női pozícióból szállnak síkra a multikulturalizmus mellett, és utasítják el ugyanakkor a nyugati feminizmust. Nurah W. Ammat'Ullah (1999) az antifeminista multikulturalizmus diskurzusát meghatározó tanulmánykötetben megjelent írásában a közösség és a világnézet jelentőségéről beszél a hívő muszlim nők életében. A szerző személyes tapasztalatait felidézve ír az amerikai fehér feministák lekezelő viselkedéséről, és arról vall, hogy az elhivatott életet élő muszlim nő számára a nyugati feminizmus riasztó, mert az intoleráns minden közösségi és világnézeti elkötelezettséggel szemben.

A nyugati feministák többsége valóban úgy gondolja, hogy a nemi egyenlőség, a nők politikai és munkaerő-piaci részvétele olyan vívmánya a modern nyugati társadalmak, amit meg kell védeniük. A nők korlátozása a politikai részvételben, a párválasztásban, az öltözködésben stb. és az ezt legitimáló kulturális és vallási előírások olyan gender-rezsimek elfogadását jelentik, amelyek az egyenlőséget tagadják, a férfiak uralmát és a nők alárendeltségét erősítik. Vagyis a kulturális és etnikai kisebbségek hátrányait kiegyenlíteni hivatott kollektív többletjogok a nemi egyenlőség és a női emancipáció ellen hatnak. Ezt az állítást sokan, nagyon eltérő pozícióból és hangsúlyokkal fogalmazzák meg, ezért nagyon eltérő jelentései és társadalmi funkciói is lesznek a kijelentésnek. Ezek közül kettővel foglalkozom a továbbiakban: a kisebbségi nők elnyomására hivatkozó feminista anti-multikulturalizmussal, és a konzervatív anti-multikulturalizmussal, amely a nők egyenlőségét az európai 
felsőbbrendűség stratégiai fegyvereként használja a más „kultúrákkal” szembeni harcban. Az utóbbiról kiváló elemzést ad Peter Hervik (2015), aki a dán idegenellenesség politikai és média-aktorainak stratégiáit vizsgálva állapítja meg, hogy a nacionalista iszlamofóbia diskurzusa a multikulturalizmus tagadására és a feminizmus kulturalizálására épül.

Az antimultikulturalista feminista álláspont leggyakrabban idézett szerzője, Susan Moller Okin megállapítja, hogy a férfiuralom valamilyen formában minden társadalomban jelen van, de társadalmi rétegenként vagy csoportokként eltérő mértékben nehezedik a nőkre (Moller Okin 1994). Empirikus kutatások azt bizonyítják, hogy nagyobb hatása van azokra, akik az egyenlőtlenségi rendszerek alján helyezkednek el, Amerikában például a szegény afro-amerikai nőkre. A szegénység nemi képzeteket és erkölcsöket konzerváló hatása a család, a rokonság, az etnikai közösség kontrollján keresztül érvényesül. Vagyis, vonja le a következtetést Moller Okin, ha a kisebbségi közösségek kultúramegőrző törekvését mindenféle mérlegelés nélkül támogatják, akkor azokat a hagyományokat is erősíteni fogják, amelyek a nőket diszkriminálják. Moller Okin elismeri, hogy patriarchális vonásai ugyan a nyugati társadalmaknak is vannak, és az emancipáció bizonyos formái a nem nyugati és nem liberális társadalmakban is jelen vannak. Ám határozottan kijelenti, hogy azokat a kisebbségi kultúrákat, amelyek ellentmondanak a nemi egyenlőség elvének, és hátráltatják a nők felszabadítását, nem lehet, és nem is szabad megvédeni. Egy patriarchális kisebbségi kultúra egy kevésbé patriarchális többségi kultúra környezetében női szempontból nem támogatandó (Moller Okin 1999:22).

Moller Okin (1999) azt a klasszikus kérdést is felteszi, mi legyen azokkal a kisebbségi kultúrákkal, amelyek ellentmondanak a nemi egyenlőség normájának. A 80-as években Franciaországban sokat beszéltek arról, hogy a magrebi országokból származó lányok viselhetnek-e fejkendőt az iskolában. A szekuláris oktatási rendszer a szélsőjobboldali aktivistákkal és a feministákkal karöltve érvelt ellene, míg a multikulturalizmus híveit támogatták a szocialisták. Ugyanakkor, hívja fel a figyelmet a szerző, a francia nyilvánosság agyonhallgatta a poligámia tényét a bevándorló muszlimok között. Az első kendő-vita idején már 200.000 poligám család élt Párizsban, jelentős részük szegénységben, ezért egymással összezárva, ugyanakkor a nyilvánosság elől elzárva. (Később szigorú törvényt hoztak, amely tiltja a poligámiát, de amiatt, hogy utólag is helyre kellett állítani, vagyis meg kellett szüntetni a poligám családi kötelékeket, számos konfliktus származott belőle.)

A szerző a történetnek azt a tanulságát emeli ki, hogy a közösségi jogok harcosai vajmi kevés figyelmet szentelnek a privátszférának, illetve azoknak a kulturális gyakorlatoknak és szerepeknek, amelyeket a kisebbségi közösségek a privátszférán keresztül valósítanak meg. Pedig a privátszférára és az aktorok nemére irányuló együttes figyelem segít felismerni, hogy a megvédeni vágyott kulturális gyakorlatok/tradíciók a nők életét mélyebben meghatározzák, mint a férfiakét. A nők idejük nagyobb részét töltik ugyanis a magánszférában, a családban és a reproduktív feladatok teljesítésével. A reprodukció a nők feleli uralom legérzékenyebb területe, ami úgy valósul meg, hogy a reprodukció fölötti kontrollt a nők testén át a férfiak gyakorolják. A magánszféra jelentőségét mutatja az is, hogy a kisebbségi nők elleni diszkrimináció a legritkább esetben történik a nyilvánosság előtt, hanem általában a magánszférában, aminek hatását növelik a többnyire férfiak által gyakorolt közösségi jogok (melyek egyben megnehezítik az igazságszolgáltatás hozzáférését).

Más feminista szerzők a kendő-viták mögötti politikai stratégiákat emelik ki, rávilágítva, hogy a muszlim 
nők által viselt fejfedő körüli európai viták legalább annyit elárulnak az európai társadalmakról, mint a muszlim nőkről, itt vagy a világ más részein (Scott 2007). A francia kendővita, mondja a gender történetírás-klasszikusa, annak az európai közéleti diskurzusnak a szimbolikus objektivációja, amely a bevándorlók és az európaiak közötti különbségeket emeli ki, és a különbségeket eltérő, sőt, egymással összeegyeztethetetlen kultúrák harcaként prezentálja. A kendő tilalmáról szóló vita nem csak a kendő újfajta - a kibocsátó muszlim társadalmak jelentés- és praxisbeli sokféleségéhez képest homogén és hegemón - jelentését hozza létre, hanem azt a társadalmi kontroll tárgyává is teszi: vagyis a muszlimok mássága fölötti kontroll a női fejkendő viseletén keresztül (és nem a férfiak ruházatán, testén vagy viselkedésén keresztül) valósul meg. Mi több, ahogyan Scott 2007-es könyvében rávilágít, a muszlim nők kendője a „veszélyes másságot” megtestesítő vízió, amely a francia társadalom rasszizmusát, posztkoloniális búntudatát és félelmét, nacionalizmusát, szekularizmusát és individualizmusát hivatott elfedni (Scott 2007:10).

A társadalmi praxisok és a politikai szimbólumok ambivalenciájának elemzéséhez még erősebb kritika társul a posztkoloniális pozícióból beszélő antropológusok munkájában. Abu Lughod (2002) a muszlim nők megmentésére irányuló politikai diskurzusokat bírálja, rámutatva a mögöttük álló katonai beavatkozások által elkövetett még nagyobb károkra, amelyekre a helyi feministák sok helyen (például Afganisztánban) hiába hívták fel a figyelmet. Abu Lughod bemutatja a női fejkendőviselet változatosságát és a változatokat kitermelő és fenntartó társadalmi és politikai folyamatokat. Kiemeli azokat az Európában kevésbé ismert eseteket, amelyekben a test vagy fej elfedését a hetvenes évektől tanult és dolgozó, sokszor a közélet iránt is elkötelezett nők gyakorolták a közel-kelet számos országában.

A multikulturalizmus és a feminizmus vitája, némi késéssel ugyan, de Kelet-Közép Európában is aktuálissá vált. A reproduktív jogok és az egészséghez való hozzáférés egyenlőtlenségei voltak az első témák, melyekkel kelet-európai roma női aktivisták a nyilvánosság elé léptek. A legintimebb kérdések politikai tematizálása nemcsak kulturális tabukat érintett, de a roma nők hangtalanságára (voice-lessness) vonatkozó közmegegyezést is felrúgta. Mi több, a kisebbségi reprezentáció maszkulinitásával is szembeszálltak; a reprodukció és az egészség kérdése körül megteremtették a roma női politika legitimációját. Fontos azonban hozzátenni, hogy ez a változás aligha történt volna meg, ha a roma nők befogadása a nőmozgalomba és az emancipációt támogató európai politikákba el nem kezdődött volna már egy évtizeddel korábban. Az Európa Tanács felkérésére 2004-re készült el egy jelentés $A$ roma/cigány nők helyzete Európában címmel, amelynek többségében roma aktivista nők által alkotott szerzői közösségét a Nyílt Társadalom Intézet, nemzeti és nemzetközi női szervezetek támogatták, hogy meg tudják fogalmazni álláspontjukat a tradíciók és a modern társadalmi igények, a közösségi elkötelezettség és az univerzális női jogok közötti konfliktusokat illetően (Mihalache 2004, Vincze 2014). Ha a politikai szerveződés folytonossága meg is szakadt, nagyon fontos intellektuális hatása volt a feminista és posztkoloniális tanulmányokat folytató akadémiai kutatóknak, akik az interszekcionalitás szemléletének honosításával megteremtettek egy analitikus nyelvet, amelyen a roma női tapasztalat leírhatóvá és értelmezhetővé vált (Jovanović-KóczéBalogh 2015). 


\section{A PROBLÉMA FELOLDÁSA:}

\section{„A MULTIKULTURALIZMUST FEMINIZÁLNI, A FEMINIZMUST MULTIKULTURALIZÁLNI KELL”}

A multikulturalizmust a feminizmussal szembehelyező álláspont Leti Volpp (2001) szerint téves. Azért tévednek a feministák (közöttük Moller Okin is), mert azt gondolják, hogy a nem nyugati kultúrákban élő nők sokkal sebezhetóbbek, mert jobban ki vannak szolgáltatva a saját kultúrájuknak, mint nyugati társaik. Ez a szemlélet szerinte azért hamis, mert elvitatja a nem-nyugati nőktől az ágenciára való képességet (denies that women have agency within patriarchy), ugyanakkor elfeledkezik az elnyomásnak azokról a formáiról, amelyek a nyugati társadalmak, legfőképpen az USA kultúrájának fontos, bár kétségtelenül sokkal rejtettebben múködő sajátoságai. A kultúrára mint egy zárt egységre tekint, holott a patriarchális rend, amit egy konkrét közösségben megfigyelhetünk, csak részben helyi jelenség, részben a kolonializmus és rasszizmus globális formáinak, valamint olyan transznacionális jelenségeknek a következménye, mint a vallási fundamentalizmusok. A kultúrafogalom megnehezíti, hogy azokat a társadalmi, gazdasági, politikai folyamatokat lássuk, amelyek eredőjeként a patriarchális viszonyok létrejönnek. És még inkább megnehezíti azt, hogy el tudjuk képzelni az ágenciát az elnyomottak részéről, vagyis azt, hogy a nem nyugati nők nem csak elszenvedik, hanem alakítják is a patriarchális viszonyokat, beleértve az ellenállás különböző módjait.

A szerző végül konstruktív dialógusra tesz javaslatot, amely meghaladja feminizmus és multikulturalizmus leegyszerűsitő dichotómiáját, és elsősorban a két kritikai diskurzus által feltárt jelenségek hasonlóságaira, illetve a mögöttük álló strukturális adottságok azonosságára hívja fel a figyelmet (Volpp 2001:1218). Ezt a célt követem én is, amikor a multikulturalizmus és a feminizmus összeférhetősége mellett érvelek. Annak áttekintéséből indulok ki, hogy a feminizmus és multikulturalizmus (az ellenideológiák mai népszerúségének ellenére) miként váltak a progresszív politikai és társadalmi gondolkodás szerves és elidegeníthetetlen részévé. Ezt követően azt gondolom át, hogy milyen módjai képzelhetők el a két kritikai és emancipatorikus eszme összekapcsolásának, vagyis a multikulturalista feminizmusnak vagy a nemi egyenlőségre érzékeny közösségi jogoknak.

Ellentmondásossága miatt a multikulturalizmus egyszerre tud a multietnikus és multikonfesszionális társadalmak önképét megújító ideológia és a kisebbségi fundementalizmusok melegágya lenni. Utóbbi valóban magába rejti a nemi elnyomást, vagyis azt, hogy legitimálják a kisebbségi nőknek a kisebbségi férfiakhoz és többségi nőtársaikhoz viszonyított alárendelt helyzetét. Ezt az ellentmondást azonban már többen felismerték, és olyan javaslatokkal éltek, amelyek elképzelhetővé teszik, hogy az etnikai kisebbségek elismerése úgy valósuljon meg, hogy közben a női jogok se sérüljenek. Will Kymlicka szerint a kisebbségeknek nyújtandó kollektív támogatást egy, a többségi társadalomra jellemző értékrendbeli minimum (liberális minimum) betartásához kell kötni. Dominique Deveaux (2006) még határozottabb álláspontot képvisel: az államot fel kell hatalmazni arra, hogy ellenőrizze, a kisebbségi közösségek nőtagjai szóhoz jutnak-e, és szorgalmazza részvételüket a döntéshozatal formális folyamataiban, továbbá azokban a nyilvános vitákban is, amelyek a kisebbségi közösség és kultúra mibenlétéről folynak. Seyla Benhabib (2001) szerint a többségi társadalmakhoz hasonlóan a kulturális kisebbségekkel is el kell fogadtatni az egyén autonómiáját (autonomous agency), ami nem zárja ki a kisebbségi közösségeknek nyújtott támogatást. Csupán azt jelenti, hogy a kisebbségi közösségek tagjai (és elsősorban a nők és a gyerekek) számára egyszerre kell biztosítani az egyenlő állampolgárok közösségéhez és kisebbségi közösséghez való tartozás lehetőségét. 
Ha elfogadjuk azt, hogy a multikulturalizmus, mely kompatibilis ugyan kisebbségi közösségi ideológiákkal, de sokkal inkább egy eltérő kulturális, vallási és nyelvi közösségből álló társadalom önreflexív diskurzusa, akkor nem nehéz elképzelni, hogy a feminizmus és a multikulturalizmus támaszkodhat egymásra. Bhikhu Parekh (2002) a brit kritikai multikulturalizmus gujarati származású politikai elméletalkotója szerint a multikulturalizmus diskurzusának két kulturális dialógust kell erősítenie: a közösségek közöttit, amely a különböző kultúrák értékeivel való együttélés tudatosságát erősíti, valamint a saját értékek folyamatos felülvizsgálatát a közösségeken belül. A Parekh köszöntésére tavaly megjelent könyvben Monica Mookherjee (2015) rámutat a két mozgalmi hátterú társadalomkritikai diskurzus lehetséges szinergiáira. A multikulturalizmust feminizálni, a feminizmust pedig multikulturalizálni kell, hogy a magukat univerzálisnak gondoló, valójában mélységesen hegemón és patriarchális kulturális zárványokat fel lehessen nyitni. A multikulturális feminizmus, ahogyan azt Mookherjee nyomán elképzeljük, nem egymás ellenére, hanem egymás erősítésére használja a két irányzatot: a multikulturalizmust a nemek közötti igazságosság megvalósítására, a feminizmust pedig a mulikulturalizmus kiteljesítésre.

\section{KONKLÚZIÓ}

Az emancipatorikus és kritikai diskurzusok bumeráng-effektusainak zajos és látványos volta, különösen, ha ehhez hozzávesszük a pro-gender és pro-multikulturalizmus diskurzusok hazai gyengeségét, jelzi, hogy a magyar társadalmat (nem egyedülálló módon) korlátozottan tudta áthatni az egyenlőség és az emancipáció eszméje. A propagandisztikus célokra használható pánikkeltést azonban nem szabad összetéveszteni a valósággal. Az, hogy valaki azt mondja, a multikulturalizmusnak vége, nem azt jelenti, hogy a multikulturalizmusnak valóban vége volna. Azt jelenti csupán, hogy valaki le akarja járatni, el akarja lehetetleníteni a multikulturalizmus diskurzusát. Ettől még a kulturális sokféleség és keveredés hétköznapi és begyakorlott formái, amelyek az európai társadalmak többségében a multikulturalizmus társadalmi alapját alkották, továbbra is múködnek. Mint ahogyan a nemi egyenlőségnek is van egy habituálódott aspektusa, amit nem lehet már politikai beszédekkel felszámolni. Elismertségüket azonban kétségtelenül alá lehet ásni; amivel szemben a társadalomkutató nem tehet egyebet, mint kitart a társadalmi progresszió elgondolása mellett. 


\section{HIVATKOZÁSOK}

Abu-Lughod, L. (2002) Do Muslim Women Really Need Saving? Anthropological Reflections on Cultural Relativism and Its Others. American Anthropology, 104(3):783-790. http://dx.doi.org/10.1525/aa.2002.104.3.783

Ammat'Ullah, N. W. (2006) Making the Distinction between Faith and Religion: A Challange to Secular Feminism. In Warren, J. W. (szerk.) Feminism and Multiculturalism. How Do They/We Work Together? Cambridge: Cambridge Scholar Press, 12-17.

Benhabib, S. (2001) The Claims of Culture: Equality and Diversity in the Global Era. Princeton, NJ: Princeton University Press.

Cohen, J. - Howard, M. - Nussbaum, M. (szerk.) (1999) Is Multiculturalism Bad for Women? Princeton, NJ: Princeton University Press.

Deveaux, D. (2006) Gender and Justice in Multicultural Liberal States. Oxford: Oxford University Press.

Habermas, J. (1997) Harcok az elismerésért a demokratikus jogállamban. In Multikulturalizmus. Budapest: Osiris-Láthatatlan Kollégium, 153-172.

Hervik P. (2015) What is in the Scandinavian Nexus of 'Islamophobia, Multiculturalism, and Muslim-Western Relations'? Intersections. EEJSP, 1(1): 66-82. http://dx.doi.org/10.17356/ieejsp.v1i1.29

Joppke, Ch. (1996) Multiculturalism and immigration: A comparison of the United States, Germany and Great Britain. Theory and Society, 25: 449-500. http://dx.doi.org/10.1007/bf00160674

Jovanović, J. - Kóczé, A. - Balogh, L. (2015) Intersections of Gender, Ethnicity, and Class: History and Future of the Romani Women's Movement. Working Paper. Budapest: Friedrich Ebert Stiftung - CEU Center for Policy Studies. http://archive.ceu.hu/sites/ default/files/publications/fes-cps-working-paper-roma-women-gender-politics-2015.pdf

Kováts E. - Põim, M. (2015) (szerk.) Gender as symbolic glue. The position and the role of conservative and far right parties in the antiGender mobilizations in Europe. Budapest: Friedrich Ebert Stiftung. http://library.fes.de/pdf-files/bueros/budapest/11382.pdf.

Kováts E. - Põim, M. - Tánczos J. (2015) A genderen túl? A genderellenes mozgósitások tanulságai a progressziv szereplők számára. Foundation for European Progressive Studies és Friedrich-Ebert-Stiftung. http://www.fesbp.hu/common/pdf/FEPS_FES_PoliCy_Brief_2015_HU.pdf.

Kováts E. - Soós E. P. (2014) Félelem a dominó-elvtől? A gender-ellenes európai mobilizáció jelensége. Francia esettanulmány és magyar kilátások. Társadalmi Nemek Tudománya, 2014/2, 106--124. http://tntefjournal.hu/vol4/iss2/kovats_soos.pdf.

Kymlicka, W. (1998) Ethnic Relations and Western Political Theory. In Opalski, M. (szerk.) Managing Diversity in Plural Societies: Minorities, Migration and Nation-Building in Post-Communist Europe. Ottawa: Forum Eastern Europe.

Mihalache I. (2004) Romani Women's Participation in Public Life. European Roma Rights Centre. http://www.errc.org/article/romaniwomens-participation-in-public-life/1359

Moller Okin, S. (1994) Gender Equality and Cultural Differences. Political Theory, 22(1):5-24. http://dx.doi.org/10.1177/0090591794022001002

Moller Okin, S. (1999) Is Multiculturalism Bad for Women? Princeton, NJ: Princeton University Press.

Mookherjee, M. (2015) At the Borders of Otherness: Tracing Feminism through Bhikhu Parekh's Multiculturalism. In Uberoi, V. Modood, T. (szerk.) Multiculturalism Rethought. Interpretations, Dilemmas and New Directions. Essays in honour of Bhikhu Parekh. Edingburgh University Press, 97-125.

Neményi M. (1994) „Miért nincs Magyarországon nőmozgalom?” In Hadas M. (szerk.) Férfiuralom. Budapest: Replika Kör, 235-45.

Parekh, B. (2002) Rethinking Multiculturalism: Cultural Diversity and Political Theory. Cambridge, Massachusets: Harvard University Press.

Scott, J. W. (2007) The Politics of the Veil. Princeton University Press.

Taylor, Ch. (1997) Az elismerés politikája. In Feischmidt M. (szerk.) Multikulturalizmus. Budapest: Osiris-Láthatatlan Kollégium. 124-152.

Torbó A. (2015) „Árpád is terrorista volt?” A multikulturalizmus hazai értelmezése a médiában. Kézirat.

Vertovec, S. - Wessendorf, S. (2010) Introduction: assessing the backlash against multiculturalism in Europe. In uók. (szerk.) The Multiculturalist Backlash. European discourses, Policies and Practices. London: Routledge, 1-30.

Vincze, E. (2014) Roma Women's Voices and Silences on Unjust Power Regimes. European Roma Rights Centre. http://www.errc.org/ roma-rights-journal/roma-rights-2013-national-roma-integration-strategies-what-next/4238/7

Volpp, L. (2001) Feminism versus Multiculturalism? Columbia Law Review, 101(5):1181-1218.

Young, I. M. (2001) Az elnyomás öt arca. In Csillag M. et al. (szerk.) Perspektivák egy tágra zárt társadalomban. Konferencia kiadvány, Budapest: Társadalomelméleti Kollégium, 11-31. 
Ez a tanulmány javított változata, ami az eredeti 2016. június 4-én közölt változathoz képest - az alábbi hivatkozásokban szereplők határozott kérésének megfelelően 2016. június 6-án reggelig az alábbiakban változott:

Kováts E. - Põim, M. (2015) (szerk.) Gender as symbolic glue. The position and the role of conservative and far right parties in the anti-Gender mobilizations in Europe. Budapest: Friedrich Ebert Stiftung. A kötet a bibliográfiában helytelen linkkel szerepelt. A jelenlegi változatban szereplő helyes link ez: http://library.fes.de/pdf-files/bueros/budapest/11382.pdf

A 105. oldalon szereplő idézet helyesen Kováts E. - Soós E. P. (2014) Félelem a dominó-elvtől? A gender-ellenes európai mobilizáció jelensége. Francia esettanulmány és magyar kilátások. Társadalmi Nemek Tudománya e-Folyóirat, 2, 106-124. http://tntefjournal.hu/vol4/iss2/kovats_soos.pdf 108. oldalán található.

Az - ugyanezen - idézetet bevezető és értelmező részhez tartozó hivatkozások köre kiegészült a Kováts E. - Põim, M. - Tánczos J. (2015) A genderen túl? A genderellenes mozgósítások tanulságai a progresszív szereplök számára. Foundation for European Progressive Studies - Friedrich-EbertStiftung. http://www.fesbp.hu/common/pdf/FEPS_FES_Policy_Brief_2015_HU.pdf címü munkára való hivatkozással.

2016. június 7. 